\title{
Author Correction: An NF-kB-microRNA regulatory network tunes macrophage inflammatory responses
}

\author{
Mati Mann ${ }^{1}$, Arnav Mehta1,2, Jimmy L. Zhao ${ }^{3,4}$, Kevin Lee1, Georgi K. Marinov (1) 1, Yvette Garcia-Flores ${ }^{1}$, \\ Li-Fan Lu ${ }^{5,6}$, Alexander Y. Rudensky ${ }^{7} \&$ David Baltimore ${ }^{1}$
}

Correction to: Nature Communications https://doi.org/10.1038/s41467-017-00972-z, published online 11 Oct 2017.

Li-Fan Lu and Alexander Y. Rudensky, who supplied miR-146a floxed mice used in this study, were inadvertently omitted from the author list in the originally published version of this Article. This has now been corrected in both the PDF and HTML versions of the Article. The generation of the floxed mice has been described in detail by Cho and Lee et $\mathrm{al}^{1}$.

Published online: 16 August 2018

\section{References}

1. Cho, S. et al. Differential cell-intrinsic regulations of germinal center B and

T cells by miR-146a and miR-146b. Nat. Commun. 9, 2757 (2018).

\begin{abstract}
(c) Open Access This article is licensed under a Creative Commons Attribution 4.0 International License, which permits use, sharing, adaptation, distribution and reproduction in any medium or format, as long as you give appropriate credit to the original author(s) and the source, provide a link to the Creative Commons license, and indicate if changes were made. The images or other third party material in this article are included in the article's Creative Commons license, unless indicated otherwise in a credit line to the material. If material is not included in the article's Creative Commons license and your intended use is not permitted by statutory regulation or exceeds the permitted use, you will need to obtain permission directly from the copyright holder. To view a copy of this license, visit http://creativecommons.org/licenses/by/4.0/.
\end{abstract}

(c) The Author(s) 2018

\footnotetext{
${ }^{1}$ Division of Biology and Biological Engineering, California Institute of Technology, Pasadena, CA 91125, USA. ${ }^{2}$ David Geffen School of Medicine, University of California, Los Angeles, CA 90095, USA. ${ }^{3}$ Department of Medicine, New York Presbyterian Hospital, Weill Cornell Medical College, 525 E 68th Street, New York, NY 10065, USA. ${ }^{4}$ Division of Hematology Oncology, Memorial Sloan Kettering Cancer Center, 1275 York Avenue, New York, NY 10065, USA. ${ }^{5}$ Division of Biological Sciences, University of California, San Diego, La Jolla, CA 92093, USA. ${ }^{6}$ Moores Cancer Center, University of California, San Diego, La Jolla, CA 92093, USA. ${ }^{7}$ Howard Hughes Medical Institute and Immunology Program, Ludwig Center at Memorial Sloan-Kettering Cancer Center, Ludwig Center at Memorial Sloan-Kettering Cancer Center, New York, NY 10065, USA. Correspondence and requests for materials should be addressed to M.M. (email: mati@caltech.edu) or to D.B. (email: baltimo@caltech.edu)
} 